\title{
非静水圧準三次元解析法による北上川の 津波河川遡上・氾濫流の一体解析
}

\author{
松井 大生 1 - 内田 龍彦 2 -中村 賢人 3 ・服部 敦 3 ・福岡 捷二 4 \\ 1学生会員 中央大学大学院 理工学研究科都市環境学専攻（†112-8551 東京都文京区春日1-13-27） \\ E-mail:matsui@civil.chuo-u.ac.jp \\ 2正会員 中央大学研究開発機構教授 (同上) \\ E-mail:utida@tamacc.chuo-u.ac.jp \\ 3正会員 国土交通省国土技術政策総合研究所 河川研究部河川研究室 \\ （テ305-0804 茨城県つくば市旭1番地） \\ 4フェロー 中央大学研究開発機構教授（干112-8551 東京都文京区春日1-13-27） \\ E-mail: sfuku@tamacc.chuo-u.ac.jp
}

\begin{abstract}
津波の河川遡上・氾濫流解析においては, 流れの三次元性を考慮でき, 種々の現象を一体的に解析が可 能な実用的なモデルが求められている. 本研究では, 平面二次元解析の枠組みで流速と圧力の鉛直分布を 考慮できる一般底面流速解析法を水面の時空間変化の激しい津波解析に応用するため, 鉛直方向流速の非 定常項と水面での圧力鉛直勾配項を新たに導入した非静水圧津波準三次元解析法を開発した。まず，本解 析法を津波河川遡上実験に適用し，実験結果と平面二次元解析法の計算結果との比較から, 本解析法の妥 当性，有用性を示した．次に，本解析法を用いて，北上川の今次津波の再現解析を行った．計算結果は， 全体的な痕跡と津波の到達時間などの特徴を再現した。 しかし, 計算水位が痕跡水位よりも大きく見積も られており，この差が生じる原因を考察した.
\end{abstract}

Key Words : non-hydrostatic quasi-3D model, tsunami, run-up in rivers, the Kitakami River, tsunami run-up experiments

\section{1. 序論}

東日本大震災に伴う津波被害を受けて，河川が津波の 主要な経路となることで，津波が河川遡上し，堤防越流 や破堤を生じ津波汇濫被害を拡大させることが改めて明 らかとなった．今後起こりうる津波に対する効果的な被 害軽減対策のためには，津波の伝播から河川遡上，汇濫 流までを一体的に再現できる数值解析法が必要である.

津波の河川遡上及び汇濫の数值解析には, 浅水流方程 式に基づく平面二次元解析法が多く用いられ，浸水深・ 最大水位，津波到達時間の再現や予測を目的とした解析 が行われる1). 浅海域や河川内など水深に対して津波波 高が無視できない場合, 波の分裂現象を考慮するため, 非線形分散波理論を用いた津波伝播解析法が改良解析法 として提案されている2)3）．しかし，津波の波長は全体 としては非常に長いことに対し, 河川遡上・汇濫する津 波は水深が浅く, フルード数が大きいため, 津波の波の 性質と同様に流れの性質が重要となり，底面の抵抗によ る流速鉛直分布の変形を考慮する必要がある。一方，防 潮堤や河川堤防などの土木構造物や津波防護施設の津波
に対する効果や而性を評価するには，流れの三次元性が 重要となるため, 構造物の周辺に非静水圧の三次元解析, その外側には平面二次元解析を用いるハイブリッドモデ ルの津波解析法が開発されている4 は, 重要な箇所の計算精度を向上させ，現象を適切に解 析できる実用的な解析法である. しかし, 解析方法が異 なるため境界接続の評価方法が容易ではない，さらに， スケールが異なる様々な現象の相互作用を解析する必要 がある津波河川遡上・汇濫流解析では, あらかじめ三次 元解析が必要な箇所を見極めて解析することは困難であ る上，現象を適切に表現するためには広範囲の箇所で流 れの三次元性を考慮する必要があると考えられる，その ため, 多重スケール現象とその相互作用を一体的に解析 できる実用的な解析法が求められる.

内田・福岡引は，平面二次元解析の枠組みで流速と圧 力の鉛直分布を考慮できる非静水圧準三次元解析法(一 般底面流速解析法)を開発している。この解析法は河川 における洪水流・河床変動解析に適用され，種々の三次 元流れや局所洗掘現象などを説明できることが示された 例えばの》。.また，津波解析にも応用され，広域の津波伝播 
と構造物まわりの流れを一体的に解析寸る必要性が示さ れている8). しかし，この解析法は，洪水時の緩やかな 非定常性を想定して開発されてきたために，鉛直方向流 速の非定常項などが省略されている等の簡略化がされて おり, 津波の河川遡上・汇濫流の強い非定常急変流場に 対する有用性や妥当性の検討は十分でない．

津波河川遡上を主眼とした今次津波の再現解析を検討 した研究例としては，津波波高が低く，水位データが十 分に観測された利根川量や新釧路川・十勝川 ${ }^{10)}$ 対象と した検討はあるが，大規模な津波の河川遡上が生じた東 北地方の直轄河川において，津波氾濫流と一体的に再現 した検討はほとんど行われていない.

本研究では，一般底面流速解析法を応用した津波の非 静水圧準三次元解析法を開発し，大型水理模型での津波 河川遡上実験と比較して解析法の妥当性を検討する. 次 に，今次津波による北上川の津波遡上・氾濫流に開発し た解析法を適用し，痕跡データと観測水位から津波河川 遡上の再現性を検証する.

\section{2. 非静水圧準三次元津波解析法の概要と改良点}

非静水圧準三次元津波解析法の概要と従来からの改良 点を示寸. 一般底面流速解析法は, 平面二次元解析の枠 組みで流速と圧力の鉛直分布を考慮できる水深積分モデ ルである. 水深と水深平均流速場は, 水深積分連続式 (1) と流速と圧力の鉛直分布を考慮した水深積分水平方 向運動方程式(2)により解かれる.

$$
\begin{gathered}
\frac{\partial h}{\partial t}+\frac{\partial U_{j} h}{\partial x_{j}}=0 \\
\frac{\partial U_{i} h}{\partial t}+\frac{\partial U_{i} U_{j} h}{\partial x_{j}}=-g h \frac{\partial z_{s}}{\partial x_{i}}-\frac{\partial h d p_{0}}{\rho \partial x_{i}}-\frac{d p_{b}}{\rho} \frac{\partial z_{b}}{\partial x_{i}}-\frac{\tau_{b i}}{\rho}+\frac{\partial h \tau_{i j}}{\rho \partial x_{j}}
\end{gathered}
$$

ここに, $i, j=1(x), 2(y),\left(z:\right.$ 鋁直方向), $h:$ 水深, $U_{i}$ : 水深平 均流速, $g:$ 重力加速度, $z_{\mathrm{s}}$ : 水面高, $z_{b}$ : 地盤高, $d p$ : 圧力の非静水圧成分 $\left(d p=p-\rho g\left(z_{s}-z\right), p:\right.$ レイノルズ応力 の等方成分と圧力の和), $d p_{b}, d p_{0}$ : 底面, 水深平均の圧 力偏差 $\left(d p_{0}=d p_{b} / 2\right), \tau_{b i}$ : 底面せん断応力, $\tau_{i j}$ : レイノル ズ応力の非等方成分と流速鉛直分布による水平せん断応 カテンソルである.レイノルズ応力は渦動粘性係数 $v_{t}$ を 用いて表現する． $v_{t}$ は流速鉛直分布の変形による乱れ生 産を考慮した水深積分乱れエネルギー輸送方程式(3)を 用いた1方程式モデルにより計算する ${ }^{11)}$.

$$
\frac{\partial k}{\partial t}+U_{j} \frac{\partial k}{\partial x_{j}}=\frac{1}{h} \frac{\partial}{\partial x_{i}}\left(\frac{v_{t} h}{\sigma_{k}} \frac{\partial k}{\partial x_{i}}\right)+P_{k}-\varepsilon
$$

ここに, $k$ : 水深平均の乱れエネルギー, $P_{k}$ : 乱れエネ ルギーの生産項, $\varepsilon$ : 乱れエネルギーの散逸率 $\left(\varepsilon=C_{\varepsilon} k^{32}\right.$ ) $\Delta), v_{t}=C_{\mu} k^{2} / \varepsilon, \sigma_{k}=1.0$ である. 乱れスケール $\Delta$ とモデル 定数は, 灘岡・八木 $\left.{ }^{12}\right)$ が用いた標準值, $C_{d} \Delta=1.7 / h\left(C_{\varepsilon}=\right.$ 0.17， $\Delta / h=0.1) ， C_{\mu}=0.09$ をそのまま適用した.
一般底面流速解析法では, 三次関数の流速分布(4)を 仮定する.

$$
u_{i}^{\prime}=u_{i}-U_{i}=\Delta u_{i}\left(12 \eta^{3}-12 \eta^{2}+1\right)+\delta u_{i}\left(-4 \eta^{3}+3 \eta^{2}\right)
$$

ここに, $\eta=\left(z_{5}-z\right) h, \quad \Delta u_{i}=u_{s i}-U_{i}, \quad \delta u_{i}=u_{s i}-u_{b i}, u_{b i}$ : 底面流 速， $u_{i}$ : 水表面流速である. 流速と圧力の鉛直分布を計 算するため, 式(1)と式(2)を連立して, 渦度の定義式を 水深積分した底面流速方程式(5), 水深積分渦度方程式 (6), 水表面の水平方向運動方程式(7), 二重水深積分連 続式(8)及び水深積分した鉛直方向運動方程式(9)を解く.

$$
\begin{gathered}
u_{b i}=u_{s i}-\varepsilon_{i j 3} \Omega_{j} h-\frac{\partial W h}{\partial x_{i}}+w_{s} \frac{\partial z_{s}}{\partial x_{i}}-w_{b} \frac{\partial z_{b}}{\partial x_{i}} \\
\frac{\partial \Omega_{i} h}{\partial t}=R_{\sigma i}+P_{\omega i}+\frac{\partial h D_{\omega i j}}{\partial x_{j}} \\
\frac{\partial u_{s i}}{\partial t}+u_{s j} \frac{\partial u_{s i}}{\partial x_{j}}=-\left\{g-\left(\frac{\partial d p}{\partial z}\right)_{z=z_{s}}\left\{\frac{\partial z_{s}}{\partial x_{i}}+P_{s i}\right.\right. \\
W h=h\left(\frac{\partial z_{m}}{\partial t}+U_{j} \frac{\partial z_{m}}{\partial x_{j}}\right)+\frac{\partial}{\partial x_{j}}\left\{h^{2}\left(k_{2} \Delta u_{j}+k_{1} \delta u_{j}\right)\right\} \\
\frac{d p_{b}}{\rho}=\frac{\partial W h}{\partial t}+\frac{\partial h W U_{j}}{\partial x_{j}}+\frac{\tau_{b j}}{\rho} \frac{\partial z_{b}}{\partial x_{j}}
\end{gathered}
$$

ここに, $\varepsilon_{i j k}$ : Levi-Civita記号, $\Omega_{i}$ : 水深平均渦度, $W$ : 水 深平均鉛直方向流速, $w_{s}, w_{b}$ : 水面, 底面の鉛直方向流 速, $R_{\sigma i}=u_{s i} \omega_{s \sigma}-u_{b i} \omega_{b \sigma}, \omega_{s \sigma} \omega_{b \sigma}: u_{s i}, u_{b i}$ の回転, $P_{\omega i}$ : 渦度生産項, $D_{a j}$ : 移流, 回転, 乱流拡散による渦度つ ラックス, $P_{s i}$ : 水表面流速生産項(水面のごく薄い層の 下面に作用するせん断応力 $)\left(P_{s i}=\left(2 v_{t} / h^{2}\right)\left(12\left(u_{s e i}-u_{s i}\right)\right.\right.$ $\left.-\delta u_{i}\right) ， u_{s e i}=U_{i}+\delta u_{i} / 3, z_{m}=\left(z_{s}+z_{b}\right) / 2$ あ゙ある.また, 水面勾配の変化量によって砕波条件を定めており ${ }^{13)}$, 灘岡らの結果 ${ }^{14)}$ 参考に砕波限界角 $\theta$ の $\tan \theta=0.7$ と している.

一般底面流速解析法を水面の時空間変化の大きい 津波解析に応用するため, 新たに二つの項を導入し ている。一つ目は津波の強い非定常性を考慮するため に，式(9)において鉛直方向流速の非定常項を考慮した. この非定常項によって生じる圧力偏差のうち, 式(8)の 水位の時間変化項によるものは式(2)の運動方程式にお いて, Boussinesq方程式の分散項帛 3) と同じ形となる. 二 つ目は津波先端等の水面の強い曲率の影響を考慮す るため，式(7)において水面の鉛直方向圧力勾配項を， 水面における鉛直方向運動方程式(10)より評価した.

$$
-\left(\frac{\partial d p}{\partial z}\right)_{z=z_{s}}=\frac{\partial w_{s}}{\partial t}+u_{s j} \frac{\partial w_{s}}{\partial x_{j}}
$$

\section{3. 津波河川遡上実験との比較}

\section{(1) 対象とする実験の概要}

実験模型は，国土技術政策総合研究所において追波湾の 一部を含む北上川約 $10 \mathrm{~km} の$ 河道と周辺地形を現地縮尺 


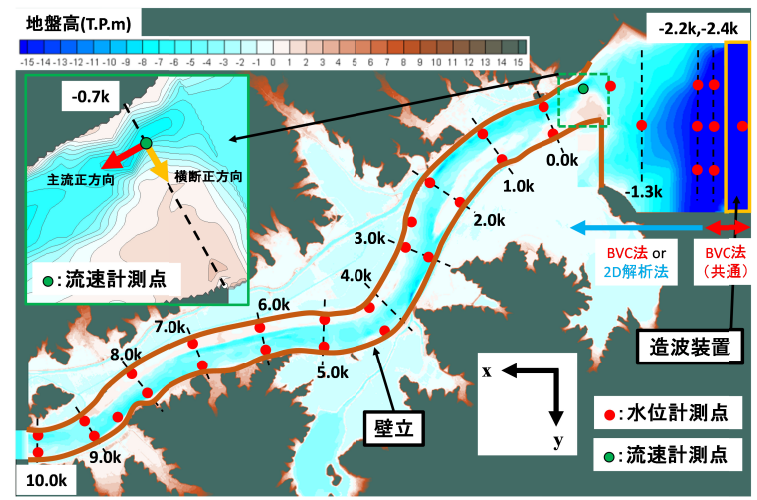

図-1 実験模型概要と水位・流速計測位置

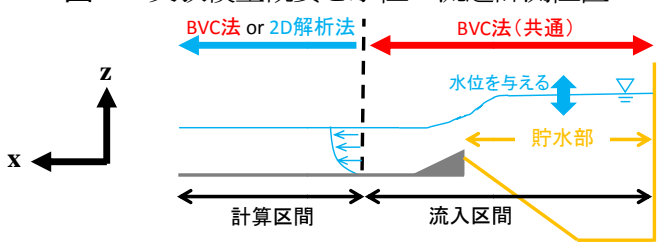

図-2 下流端境界条件の考慮方法

1/330で再現したものである. 実験模型の概要と水位, 流速の計測点を図-1に示す。模型下流端には造波装置が 設置され，造波装置前面には堰を有する貯水部があり， これを介して模型と接続している(図-2参照). 入射津波 の単純化のために追波湾の地形の一部を削って湾内の幅 を一様にしている.

河川遡上と氾濫流の一体解析法を検討寸るためには, 堤防越流と汇濫流を含む条件での実験を対象とするのが 望ましいが，本実験施設では実験縮尺の制約のため，越 流水深や汇濫水深が非常に小さくなり, 解析と比較し得 る十分な精度のデータを取得することが難しかった．そ こで本研究では, 河川堤防・海岸堤防の表法肩に垂直壁 を設置し，堤内地一の越流がなく，河道内のみを津波が 遡上する条件の下で行われたケースを対象とした．河川 流量はなく，造波前の湾内・河道内は初期水位 (T.P.+0.703m) で湛水している. 造波波形は造波可能な最 大の波高を短周期で与えたものであり，造波装置の制約 から単一波の峰のみを再現している，なお，実験は再現 性を確認するために，同一のケースを三回実施している。 そのうち一つは他の二回の実験と比べて，入射する津波 水位が全体的に低かったため，二回の実測水位波形を用 いて検討を行う。

\section{(2) 解析方法之境界条件}

解析法には, 非静水圧準三次元津波解析法(BVC法)之 平面二次元解析法(2D解析法)を用いる. なお，本研究で 用いる2D解析法では， $\tau_{i j}$ に二次式で表現した等流状態の 流速鉛直分布による運動量交換を考慮している ${ }^{11)}$. これ は，BVC法での流速鉛直分布の非平衡性が津波遡上に与 える影響を比較，検討するためである．下流端境界条件 は，造波装置から模型内一の流入流量が不明であり，湾 内のフルード数が小さくないことから, 解析領域に造波 装置を含め，湾内の津波流入部(-2.4k,-2.2k)の実測水位波 形を再現するように，造波装置前面にある貯水部の水位 を実測值を参考にして与える(図-2参照)。なお，今回の 実験ケースでは， $-2.4 \mathrm{k}$ の実測水位と流速勾配 $0(\partial w \partial x=0)$ の 下流端境界条件を与えた場合の計算結果は, 貯水部の水 位を与え流入部の地形を考慮して計算する場合と比べて 全体的な波形には大きな差は見られなかったが，湾から の流入量が多くなり, 上流側の水位が高く, 到達時間が 早くなることと局所的な水位上昇に差が見られた. 同一 の下流端境界条件でBVC法と2D解析法を比較するため, 2D解析法の計算においても，造波装置貯水部から-2.4k 測線まではBVC法を用い計算している(図-2参照)。2D解 析法の場合の流入区間と計算区間の境界では，水深hと 水深平均流速 $U_{i}$ 共有し，計算区間において流速分布は 等流の二次曲線を与えている. 上流端境界条件は実験と 同様に流出境界条件を与える，底面粗度は，上流部での 津波到達時間を再現するように，地形全体に一様に相当 粗度 $k_{5}=0.03 \mathrm{~m}$ をちえた，なお，本論文では，全ての実験 值はフルード相似に基づいて現地換算されたものであり， 再現計算は現地スケールにて行っている.

\section{(3) 再現計算結果とその考察}

図-3は, 実験結果と計算結果(BVC法・2D解析法)の水 位波形の比較である。計算結果は湾内，河道内での短周 期の水位変動を再現できていないが，流入部の全体的な 水位波形を再現できている。. また, 図-3(c)は解析結果と 実験結果の差が最も大きかった0k左岸での比較である. 第一波目通過後に大きく水位忍低下し，第二波目による 急激な水位上昇を再現できていない，これは，局所的に 地盤高が低く，第一波目通過後に射流場となり，解析に おいて水位が大きく低下したためと考えられるが，その 原因は明らかではない. しか几，この地点以外では計算 結果は全体的な波形と津波到達時間を再現している. 10k左岸では，BVC法の計算結果は2D解析法に比べ, 津 波の到達時間が遅く，波形全体の水位がわずかに低くな っている. これは，津波が河川遡上寸る際に流れの三次 元性による運動量交換や圧力の非静水圧成分が抵抗とし て働いたことが考えられる. 河川を遡上するにつれてこ の差が大きくなることから，津波遡上を扱う場合には三 次元性を考慮した抵抗評価が重要だと考えられる. 図一 3(b)を見ると，-1.3kでは2D解析法に比べ, BVC法がピー ク水位を大きく計算している. この地点は, 壁からの反 射波と流入する波が重なり非常に高いピーク水位となる. 式(9)の鉛直方向流速の非定常項を考慮しないBVC法の 解析では, 2D解析法とほとんどピーク水位が変わらな かったことから，鉛直方向流速の非定常項は急激な水位 上昇を評価するために重要と考えられる. また，水面の 鉛直方向圧力勾配項を考慮しないBVC法では, 改良した 


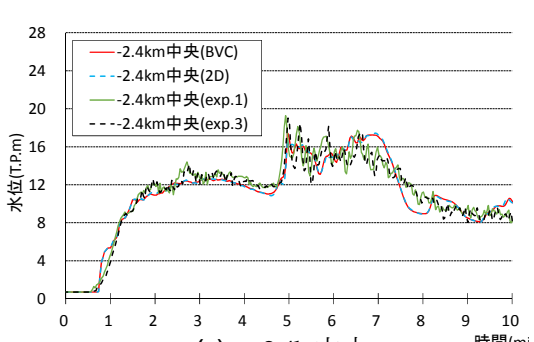

(a) $-2.4 \mathrm{k}$ 中央

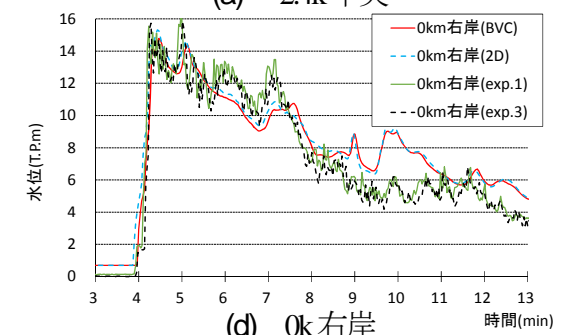

(d) $0 \mathrm{k}$ 右岸

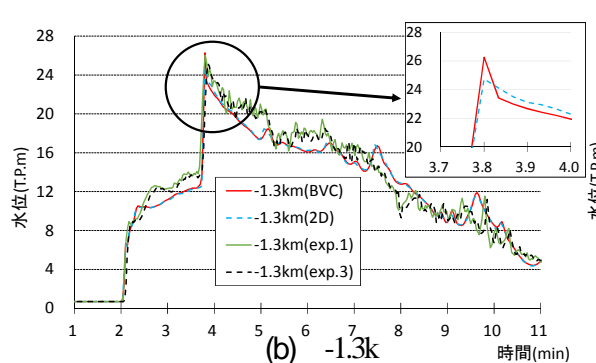

${ }^{5}(\mathrm{~b})^{6}-1.3 \mathrm{k}$

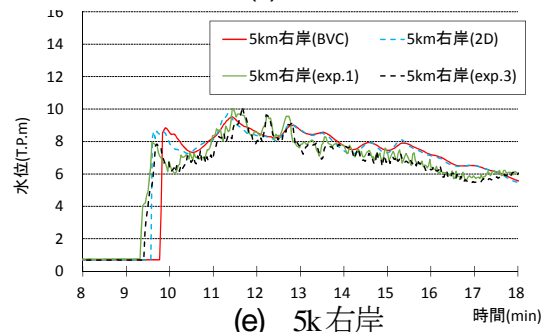

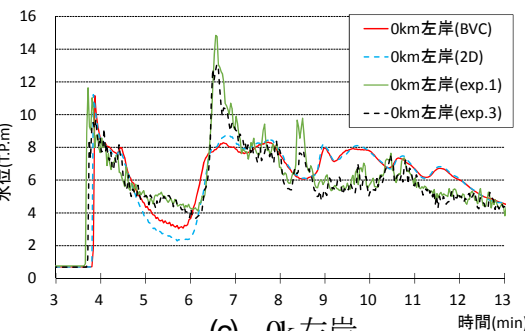

(c) $0 \mathrm{k}$ 左岸

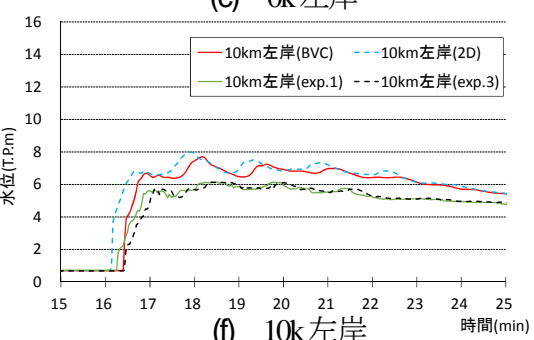

図-3 実験結果と計算結果(BVC 法・2D 解析法)の水位波形の比較

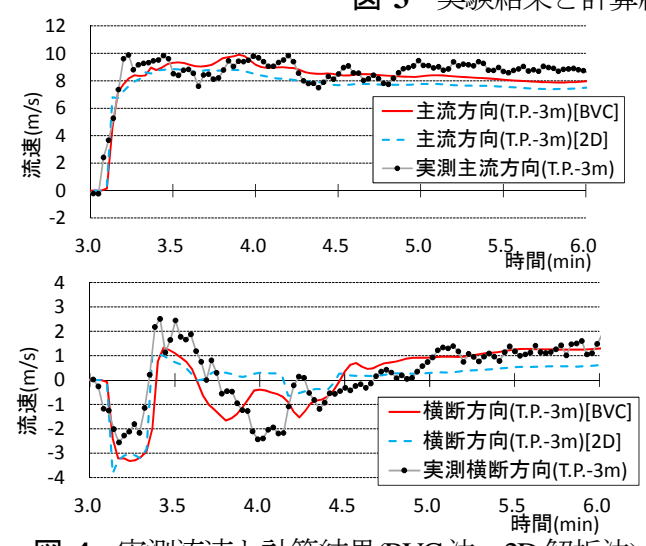

図-4 実測流速と計算結果(BVC 法・2D解析法) の比較（上 : 主流, 下 : 横断）

BVC法に比へ，津波波形が緩やかになり，津波到達時間 がわずかに遅く計算された。 しかし，改良したBVC法と 2D解析法との差に比べるとその差は小さく，今回の計 算では水面の鉛直方向圧力勾配項の影響はあまり大きく なかった．また，砕波限界角 $\theta$ を小さくして解析する と，津波波形がより減衰するようであり，実験結果 と本解析法の差は, 砕波の判定とエネルギーロスの 評価法に課題があると考えられる，この点について はさらなる検討が必要である。

図-4に-0.7kでの底面付近の実測流速と計算結果(BVC 法・2D解析法)の比較を示寸. 流速は二次元電磁流速計 を用いてT.P.-3.0mの高さで計測しており，主流・横断方 向は図-1に示寸通りである. 解析結果は同じ高さの流速 を流速鋁直分布式(4)から算出したものである．解析結 果の主流速の時間変化はBVC法, 2D解析法の差は小さ く, ともに実験結果をよく再現している. 横断方向流速 は主流速に比べ複雑に変化している.この場所は左岸側 の湾地形からの反射波と右岸側の海岸堤防上の壁からの 回折波が合わさり，二次流構造が時空間的に複雑に変化 する. BVC法による計算結果は4min付近の波形等，十分 に再現できているとは言えないが，2D解析法と比較し て実験結果の再現性は改善されていると言える.

\section{4. 今次津波による北上川の津波河川遡上 - 汇濫 流への非静水圧準三次元津波解析法の適用}

\section{(1) 解析方法と境界条件}

内田・福岡による既往の研究息より, 流れの三次元性の 影響は水深が浅く地形が複雑となる湾域や陸域での津波 汇濫流では重要となるが，水深の深い場所ではほとんど 現れないことが明らかとなっている．このことから，本 研究では，断層モデルを含む広域の津波伝播解析と追波 湾, 北上川, 汇濫域を含む詳細領域の津波遡上・汇濫流 解析の二つに分けて解析を行う.

広域の津波伝播解析において, 初期水位は東北大学モ デル(version1.2) ${ }^{15)}$ の断層モデルから与える. 用いる解析 法は2D解析法であり，メッシュスケール比1/3(1350〜 50m)の1wayネスティング手法"8適用する。広域の津波 伝播解析の計算結果を用いて, 詳細領域の湾域での境界 条件を求める.

詳細領域の津波遡上・汇濫流解析においては, 広域の

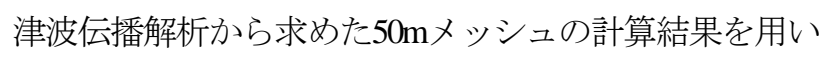
て, 湾域の水位, 流速の時空間分布を与える(図-5参照). 用いる解析法はBVC法である. 詳細領域のメッシュサイ ズは10mであり, 震災前の地形に対して地形全体一様に $70 \mathrm{~cm}$ の地盤沈下を考慮して解析地形を作成している. 津波来襲前の北上川では干潮直後の上げ潮の時間であり， 水面勾配がほとんど水平であったと考えられる．津波来 襲時の河川の流況を再現するのは困難であるため, 本解 析では河川流を考慮しないこととし, 津波到達前の河道 内，湾内の初期水位は，断層モデルによる沈下量により 与える. 北上川の実測水位データより, 約49k地点まで 津波の遡上が確認されているが，大堰付近の痕跡水位よ り, 大堰下流では反射による水位上昇, 大堰上流では津 波波高の大幅な減衰が確認されている ${ }^{16}$. このことから, 本解析では津波波高が大きい北上大堰より下流に主眼を 


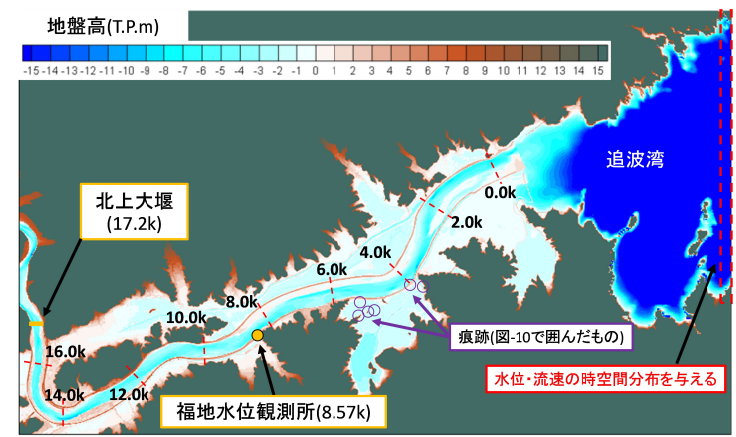

図-5 詳細計算領域

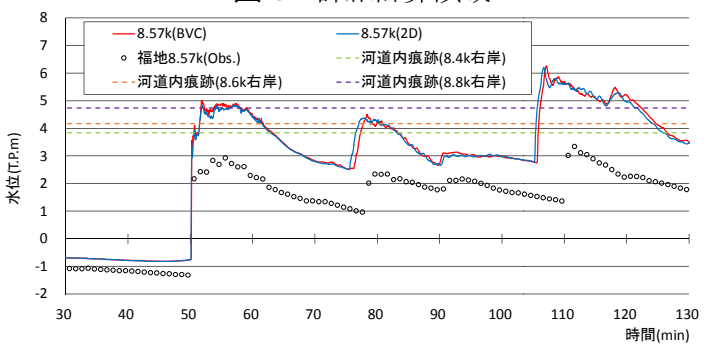

図-6 実測水位と計算結果(BVC 法-2D解析法)の比較

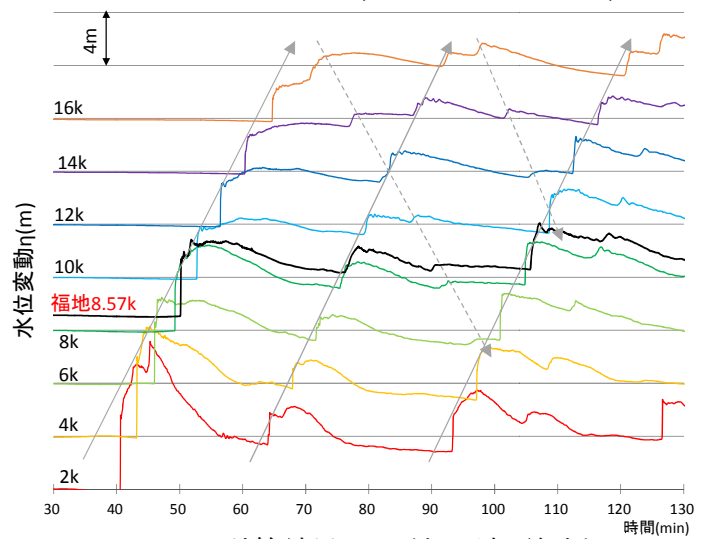

図-7＼cjkstart計算結果(BVC 法)の波形伝播

置き，北上大堰を完全反射条件として取り扱い，その上 流には津波が遡上しない条件を設定している，底面粗度 は，手引き ${ }^{11}$ に示されている值を参考に水域は $n=0.025$ と した．高水敷は植生が繁茂していることから $=0.028$, 堤内地は全て一様に $n=0.030$ とし, これらのマニングの 粗度係数をManning-Stricklerの式から相当粗度 $k_{s}$ に換算し 与えた.

\section{(2) 再現計算結果とその考察}

図-6に福地(8.57k)での実測值と計算結果(BVC法・2D解 析法)の水位波形の比較を示寸．計算結果は実測值に比 心，津波波高が大きく，周辺の痕跡水位と比べても高い 水位となっている. 模型実験の水位比較は良好であった ことから，この差は水位観測所付近の詳細な地形を考慮 していないこと，破堤を考慮していないことにも関係し ていると考えられる. しかし，各波の到達時間と全体的 な波形の特徵を再現できている. BVC法と2D解析法の 計算結果を比べると全体的な波形に大きな差は表れない が，3章の実験の場合と同様に，BVC法に比べ2D解析法 の計算結果は津波の到達時間を早く, 波の峰の水位を低

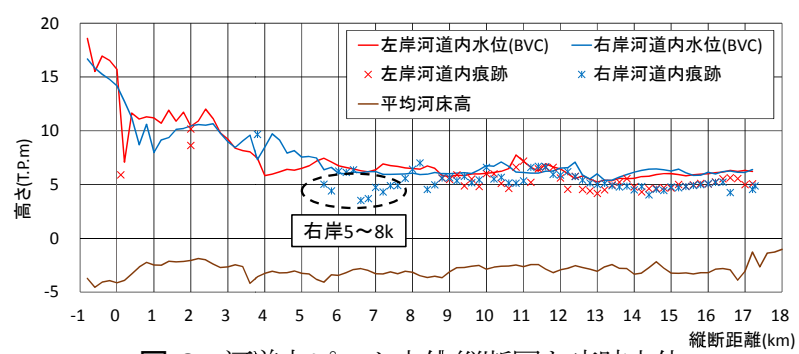

図-8 河道内ピーク水位縦断図と痕跡水位

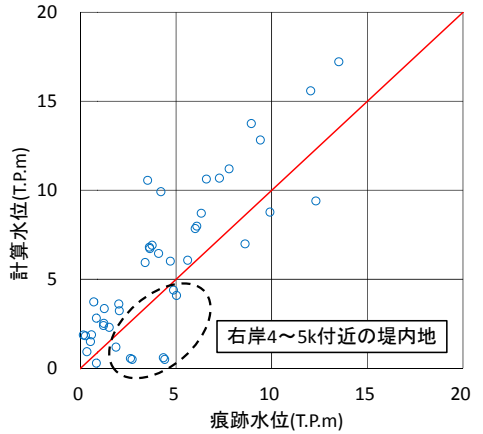

図-9＼cjkstart計算水位と痕跡水位の比較

く計算している. 図-4で示したように，局所的な流れに おいてBVC法と2D解析法の差が顕著に生じるが，両解 析法の差より実測值との差が大きいため，本研究では BVC法の計算結果と実測值を比較し，検討を行う。また， 実測水位の最大波高は，第一波の55minより後の110min

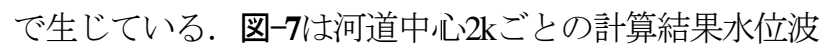
形である．波の峰を直線で結ぶと，遡上波と北上大堰か らの反射波が伝播している様子がわかる．図-7より，福 地における110minでの最大水位は，遡上波と反射波が重 なったことにより生じたと考えられる．図-8は計算結果 の河道内ピーク水位縦断図と痕跡水位の比較である. 計 算結果は痕跡水位を概衫説明できているが，13k〜北上 大堰の両岸と右岸5〜8kでは痕跡水位に比心゙計算水位が 高い，前者は，北上大堰を完全反射条件としているため に，堰を通過していく津波を無視したことが原因である と考えられる. 後者は破堤箇所(右岸 $4 \sim 5 \mathrm{k}$ 付近)の直上流 にあたる. 図-9に湾内を除いた河道内，堤内地での計算 水位と痕跡水位の散布図を示吉. 痕跡水位は東北地方太 平洋沖地震津波合同調査グループ円ฤによる調査結果であ る. 計算水位は痕跡水位に比べて全体的に高くなってい るが，破堤した右岸 4 ～ 5 堤内地(図-5参照)では痕跡水位 よりも低くなっている.これらのことから, 再現性の向 上には破堤の影響を検討することが必要であると考えら れる.

\section{5. 結論}

本研究では，一般底面流速解析法を応用し開発した非 静水圧準三次元津波解析法を模型実験と北上川の今次津 波に適用した. 得られた主要な結論を以下に示す。

1) 本解析法と北上川の津波遡上実験結果を比較し, 本解 
析法の妥当性を示した. 本解析法と平面二次元解析法 の差は全体的な波形には表れなかったが，流れの三次 元性による運動量交換と非静水圧成分が津波の減衰と 到達時間, 局所的な水位上昇に影響を与えることを明 らかにした．また，河口部の複雑な流れ場を解析する ためには，流れの三次元性を考慮した本解析法が有用 であることを示した.

2) 北上川の今次津波再現計算において，水位を大きく計 算しているが，堰からの反射による水位上昇と全体的 な痕跡水位を再現した. 福地における最大水位は, 遡 上波と反射波の重なりにより生じたことを示した．さ らなる再現性の向上には，破堤の考慮等が必要である ことを示した.

謝辞 : 本論文で使用した今次津波のデータは, 東北地方 整備局河川部から貸与頂いた。 ここに記して謝意を表す。

\section{参考文献}

1) (財) 国土技術研究センター: 津波の河川遡上解析の 手引き（案）, http://www.jice.or.jp/siryo/t1/pdf/ tsunami.pdf (2007) .

2) Sato, S.: Numerical simulation of 1993 Southwest Hokkaido earthquake tsunami around Okushiri island, J. Waterway, Port, Coastal, and Ocean Engineering, ASCE, Vol.122, No.5, pp.209-215, 1996.

3) 岩瀬浩之, 見上敏文, 後藤智明: 非線形分散波理論を 用いた実用的な津波計算モデル，土木学会論文集， No.600/ II -44, pp.119-124， 1998.

4) 正村憲史, 藤間功司, 後藤智明, 飯田邦彦, 重村利 幸: 2 次元・3 次元ハイブリッドモデルを用いた津波 の数值解析, 土木学会論文集, No.670/ II -54,pp.49-61, 2001.

5) 内田龍彦, 福岡捷二: 浅水流の仮定を用いない水深積 分モデルによる底面流速の解析法, 土木学会論文集 B1(水工学), Vol.68, No.4, I_1225- I_1230, 2012.

6) Fukuoka, S. and Uchida, T.: Toward integrated multi-scale simulations of flow and sediment transport in rivers, Jour- nal of JSCE, Ser.B1 (Hydraulic Engineering), Vol. 69, No. 4, pp. II_1-II_10, 2013.

7) Uchida, T. and Fukuoka, S.: Numerical calculation for bed variation in compound-meandering channel using depth integrated model without assumption of shallow water flow, Advances in Water Resources, Vol. 72, pp. 45-56, 2014.

8) 内田龍彦, 福岡捷二: 底面流速解析法を用いた津波に よる構造物周りの三次元流れと局所洗掘解析, 土木 学会論文集 B2(海岸工学), Vol.69, No.2, I_271- I _275, 2013.

9) 赤穂良輔, 石川忠晴: 平成 23 年東北地方太平洋沖地 震津波における利根川下流の津波遡上再現計算，土 木学会論文集 B1(水工学), Vol.68, No.4, I_1543- I _1548, 2012.

10) 阿部孝章, 吉川泰弘, 安田浩保, 平井康幸: 2011 年東 北地方太平洋沖地震に伴い発生した津波の北海道内 における河川遡上, 土木学会論文集 B1(水工学), Vol.68, No.4, I_1525- I_1530, 2012.

11) 内田龍彦，福岡捷二: 底面流速解析法による連続する 水没水制群を有する流れと河床変動の解析, 土木学 会論文集 B1(水工学), Vol.67, No.1, pp.16-29, 2011.

12) 灘岡和夫, 八木宏: 浅い水域の乱流場に関する数值計 算モデルの開発と沿岸流場への適用, 土木学会論文 集，No.473/ II -24，pp.25-34， 1993.

13) 内田龍彦, 福岡捷二: 構造物を越流寸る流れの解析法 の開発，河川技術論文集，第 18 巻,pp.351-356, 2012.

14）灘岡和夫, 大野修史, 栗原礼: 波動場の力学状態に基 づく砕波過程の解析と砕波条件, 海岸工学論文集, 第 43 巻, pp.81-85, 1996.

15) 今村文彦, 越村俊一, 馬㴊幸雄, 大家隆行, 岡田清 宏: 東北地方太平洋沖地震を対象とした津波シミュレ ーションの実施 東北大学モデル(version1.2), 東北大学 大学院工学研究科付属災害制御研究センター, 2012.

16) 茅根康佑, 田中仁, Mohammad Bagus ADITYAWAN: 津波の河川遡上に対する河床勾配の影響に関する検 討, 土木学会論文集 B2(海岸工学), Vol.68, No.2, I _176- I_180, 2012.

17) 東北地方太平洋沖地震津波合同調査グループ: 東北地 方太平洋沖地震津波情報, http://www.coastal.jp/ttjt/, (2015/2/16 参照)

(2015.3.18 受付)

\section{INTEGRATED MULTISCALE COMPUTATION OF TSUNAMI RUN-UP AND INUNDATION IN THE KITAKAMI RIVER BY THE NON HYDROSTATIC QUASI-3D MODEL}

\section{Daiki MATSUI, Tatsuhiko UCHIDA, Kento NAKAMURA, Atsushi HATTORI and Shoji FUKUOKA}

For simulation of tsunami run-up in rivers and inundation, a numerical computation method which can evaluate three dimensional flows is required to simulate several phenomena integrally. In this study, we developed a non-hydroststic quasi-3D tsunami simulation model based on the general BVC method, newly considering the unsteady term of vertical velocity and the vertical pressure gradient term on water surface. First, the present model was applied to the tsunami run-up experiments. The model was validated through the comparisons with the experimental results. Then, we applied it to the 2011 Tohoku Tsunami in the Kitakami River. Altough calculated water levels were higher than observed ones, the model reproduced water levels of tsunami traces and the arrival time. 